\title{
Interactions of Trivalent Lanthanide Cations with a New Hexadentate Di-Schiff Base: New Lanthanide(III) Complexes from (NE, $\left.N^{\prime} E\right)-2,2^{\prime}$-(ethane-1,2-diylbis(oxy))bis(N-(pyridin-2- ylmethylene)ethanamine)
}

\author{
Mantha Tsiouri, ${ }^{1}$ Konstantina Skorda, ${ }^{2}$ Christos Papadimitriou, ${ }^{1}$ Yang Li, ${ }^{3}$ \\ J. Derek Woollins, ${ }^{3}$ and John C. Plakatouras ${ }^{1}$ \\ ${ }^{1}$ Department of Chemistry, University of Ioannina, 45110 Ioannina, Greece \\ ${ }^{2}$ Faculty of Physics and Chemistry, Hellenic Army Academy, 16673 Vari, Greece \\ ${ }^{3}$ School of Chemistry, University of St. Andrews, North Haugh, St. Andrews, Fife, Scotland, KY16 9ST, UK \\ Correspondence should be addressed to John C. Plakatouras, iplakatu@cc.uoi.gr
}

Received 22 April 2010; Accepted 2 May 2010

Academic Editor: Spyros Perlepes

Copyright () 2010 Mantha Tsiouri et al. This is an open access article distributed under the Creative Commons Attribution License, which permits unrestricted use, distribution, and reproduction in any medium, provided the original work is properly cited.

The novel lanthanide(III) complexes $\left[\mathrm{Ln}\left(\mathrm{NO}_{3}\right)_{2} \mathrm{~L}\right]\left(\mathrm{NO}_{3}\right) \cdot 3 \mathrm{MeOH}(\mathrm{Ln}=\mathrm{La} \mathbf{1}, \mathrm{Pr} 2)$ and $\left[\mathrm{Ln}\left(\mathrm{NO}_{3}\right)_{3} \mathrm{~L}\right]\left(\mathrm{NO}_{3}\right) \cdot 2 \mathrm{MeOH}(\mathrm{Ln}=\mathrm{Gd}$ 3, $\mathrm{Yb} 4$ ), where $\mathrm{L}=\left(\mathrm{NE}, \mathrm{N}^{\prime} \mathrm{E}\right)-2,2^{\prime}$-(ethane-1,2-diylbis(oxy))bis(N-(pyridin-2-ylmethylene)ethanamine), have been obtained by direct reaction of the Schiff base ligand and the corresponding hydrated lanthanide(III) nitrates in methanol. All complexes were characterized spectroscopically and thermogravimetrically. Complex 4 was also characterized with crystallographic studies: orthorhombic P $2{ }_{1} 2_{1} 2_{1}, a=10.6683(14), b=13.4752(15), c=19.3320(26) \AA$. In the molecular structure of 4 , Yb(III) is surrounded by all donor atoms of the Schiff base (four nitrogen and two oxygen atoms) and four oxygen atoms belonging to two bidentate chelating nitrato ligands.

\section{Introduction}

Schiff base metal complexes have a key role in the development of coordination chemistry, resulting in an enormous number of publications, ranging from pure synthetic work to modern physicochemical and biochemically relevant studies of metal complexes [1].

The lanthanide cations can promote Schiff base condensation and can give access to complexes of otherwise inaccessible ligands. This fact, in combination with the applications of lanthanide macrocyclic complexes emerging from biology and medicine, has boosted research on these areas [2].

One of the major applications of lanthanide complexes in medicine is their use as water proton relaxation agents for NMR imaging $[3,4]$. The research in this field is directed towards the synthesis of stable, nontoxic, highly paramagnetic molecules with the ability to improve efficiently the contrast of the magnetic resonance image. The number of coordinated water molecules on the paramagnetic center (usually gadolinium(III)) greatly contributes to the relaxivity (the efficiency with which the complex enhances the proton relaxation rates of water) of the contrast agent. Initially polyaminocarboxylates were utilized as ligands for the preparation of such complexes, with $\left[\mathrm{Gd}(\mathrm{DTPA})\left(\mathrm{H}_{2} \mathrm{O}\right)\right]^{2-}\left(\mathrm{DTPAH}_{5}=\right.$ diethylenetriaminepentaacetic acid) being the most commonly used contrast agent. Though the aforementioned agent has a high stability constant, reducing the toxic effect of the free metal ion, its disadvantage is the availability of only one water coordination site.

A large number of articles have been published on lanthanide complexes with the hexadentate Schiff base derived by the condensation of 2,6-diacetylpyridine and 
ethylenediamine [5-16]. These complexes are stable enough under physiological conditions. However, only recently, research work dealing with the various aspects involving different physicochemical properties and complexation behaviour of tetradentate Schiff bases has appeared in the literature, primarily focusing on the separation of actinides from lanthanides in nuclear reprocessing [17] and catalytic properties [18].

Previously, we have reported the synthesis and the structural and spectroscopic characterization of lanthanide complexes with $\mathrm{N}, \mathrm{N}^{\prime}$-bis[1-(pyridin-2-yl)ethylidene] ethane-1,2-diamine [19] and N,N'-bis(pyridin-2-yl-methylene)benzene-1,2-diamine [20]. It was found that the ethylenediamine "hinge" of the di- Schiff base ligand eliminates the possibility of coplanar coordination of the four nitrogen donors [19] while when we changed the ethytlene diamine moiety with 1,2-phenylenediamine to force planar coordination of the tetradentate di-Schiff base, we ended up with the lanthanide cations outside of the four nitrogens plane [20]. In a different work, [21], we found that $\mathrm{N}^{\prime} \mathrm{N}^{\prime}$ bis(pyridin-2-ylmethylene)cyclohexane-1,2-diamine has an intermediate coordinating behaviour to the lanthanides.

In a previous work, the utilization of 8-hydroxyquinoline-2-carboxaldehyde for the preparation of Schiff bases leads to products with poor solubility [22]. The next step in our research is to elongate the diamine part of the above-mentioned ligands, incorporating donor atoms, and study the structure and the stability of the prepared complexes. Since the denticity of the ligands is increased, we expected more stable complexes. Herein we report the synthesis and characterization of four new lanthanide complexes with (NE,N'E)-2,2' -(ethane-1,2diylbis(oxy))bis(N-(pyridin-2-yl-methylene)ethanamine), a ligand derived by the condensation of $2,2^{\prime}$-(ethane-1,2diylbis(oxy))diethanamine and pyridine-2-carboxaldehyde.

\section{Experimental}

2.1. Materials and Instrumentation. All manipulations were carried out under aerobic conditions. Metal salts and organic molecules were purchased from Aldrich and used as received. Solvents were of analytical grade (Lab-Scan Chemical Co) and used without further purification. $\mathrm{C}, \mathrm{H}$, and $\mathrm{N}$ analyses, IR $\left(4000-370 \mathrm{~cm}^{-1}\right)$ and far-IR $\left(600-30 \mathrm{~cm}^{-1}\right)$ [20], and UV/Vis spectra in the solid state [23] and in solution, [24] thermal studies, and room temperature magnetochemical measurements [20] were carried out as previously described.

2.2. Preparation of the Compounds. The ligand (NE,N'E)-2, $2^{\prime}$-(ethane-1,2-diylbis(oxy))bis( $\mathrm{N}$-(pyridin-2-ylmethylene)ethanamine) was synthesized from the condensation of 2,2' -(ethane-1,2-diylbis(oxy))diethanamine and pyridine-2carboxaldehyde in situ.

To a stirred solution of pyridine-2-carboxaldehyde $(0.40 \mathrm{~g}, 3.73 \mathrm{mmol})$ in methanol $(15 \mathrm{~mL})$, a solution of $2,2^{\prime}-$ (ethane-1,2-diylbis(oxy))diethanamine $(0.27 \mathrm{~g}, 1.86 \mathrm{mmol})$ in methanol $(5 \mathrm{~mL})$ was added. The resulting yellowish
TABLe 1: Crystal data and structure refinement for 4.

\begin{tabular}{lc}
\hline & {$\left[\mathrm{Yb}\left(\mathrm{NO}_{3}\right)_{2} \mathrm{~L}\right]\left(\mathrm{NO}_{3}\right) \cdot 2 \mathrm{MeOH}$} \\
\hline Empirical formula & $\mathrm{C}_{20} \mathrm{H}_{30} \mathrm{~N}_{7} \mathrm{O}_{13} \mathrm{Yb}$ \\
Formula weight & 749.55 \\
Temperature & $93(2) \mathrm{K}$ \\
Wavelength & $0.71069 \AA$ \\
Crystal system, Space group & Orthorhombic, $\mathrm{P}_{1} 2_{1} 2_{1}$ \\
Unit cell dimensions & $a=10.668(5) \AA$ \\
& $b=13.475(5) \AA$ \\
& $c=19.332(5) \AA$ \\
Volume & $2779.0(18) \AA^{3}$ \\
$Z$, Density (calc.) & $4,1.792 \mathrm{~g} / \mathrm{cm}^{3}$ \\
Absorption coefficient & $3.441 \mathrm{~mm} \mathrm{~m}^{-1}$ \\
$F(000)$ & 1492 \\
Crystal size & $0.21 \times 0.1 \times 0.08 \mathrm{~mm}^{3}$ \\
Completeness to theta $=25.00^{\circ}$ & $99.6 \%$ \\
Reflections (collected/independent $)$ & $18754 / 6025[R(\mathrm{int})=0.0217]$ \\
Data/restraints/parameters & $6025 / 0 / 403$ \\
Goodness-of-fit on $F^{2}$ & 1.079 \\
Final $R$ indices $[I>2 \sigma(I)]$ & $R_{1}=0.0193, w R_{2}=0.0434$ \\
$R$ indices (all data) & $R_{1}=0.0198, w R_{2}=0.0437$ \\
Absolute structure parameter & $0.599(6)$ \\
Largest diff. peak and hole & 1.778 and $-0.743 \mathrm{e}^{-3}$ \\
\hline
\end{tabular}

solution was refluxed for $1 \mathrm{hr}$, and to this the corresponding hydrated lanthanide nitrate $(1.86 \mathrm{mmol})$ in $10 \mathrm{ml}$ of methanol was added. The resulting solutions were heated for a further $30 \mathrm{~min}$ and then was left undisturbed to evaporate at room temperature, and yielded microcrystalline solids after three days. The solids were isolated by filtration, washed with a small amount of cold methanol (ca. $2 \mathrm{~mL})$ and diethyl ether $(2 \times 10 \mathrm{~mL})$, and dried under vacuum, over silica gel. The yields were within the range of $55 \%-65 \%$. A small portion of the mother liquid of complex 4 was layered with diethyl ether to yield a few small colourless blocks, suitable for X-ray structural studies.

$\left[\mathrm{La}\left(\mathrm{NO}_{3}\right)_{2} \mathrm{~L}\right]\left(\mathrm{NO}_{3}\right) \cdot 3 \mathrm{MeOH}$ (1) Anal. Calc. for $\mathrm{C}_{23} \mathrm{H}_{34} \mathrm{~N}_{7} \mathrm{O}_{14} \mathrm{La}: \mathrm{C}, 35.80 ; \mathrm{H}, 4.45 ; \mathrm{N}, 12.71$. Found: C, 35.96; H, 4.09; N, 12.57\%. Selected IR data $\left(\mathrm{cm}^{-1}\right): 3377 \mathrm{mw}$ $[\mathrm{m}(\mathrm{O}-\mathrm{H})], \quad 3070 \mathrm{w} \quad\left[\mathrm{m}(\mathrm{C}-\mathrm{H})_{\mathrm{ar}}\right], \quad 2980 \mathrm{w} \quad\left[\mathrm{m}(\mathrm{C}-\mathrm{H})_{\mathrm{al}}\right]$, $1759 \mathrm{~m}, 1733 \mathrm{~m}\left[\nu_{1}+\nu_{4}\right.$ of the nitrate], $1641 \mathrm{~s}[\mathrm{~m}(\mathrm{C}=\mathrm{N})]$, $1590 \mathrm{~ms}, 1572 \mathrm{~m}$ [ring stretching vibrations], 1492 versus $\left[v_{1}\left(\mathrm{~A}_{1}\right)\right.$ of the nitrate $], 1309$ versus $\left[v_{5}\left(\mathrm{~B}_{2}\right)\right.$ of the nitrate], $1018 \mathrm{~m}\left[v_{2}\left(\mathrm{~A}_{1}\right)\right.$ of the nitrate], $636 \mathrm{~m}[\delta(\mathrm{py})], 410 \mathrm{w}[\gamma(\mathrm{py})]$. TGA/DTA $\left(\mathrm{N}_{2}, 1 \mathrm{~atm}\right): 50^{\circ} \mathrm{C}-91^{\circ} \mathrm{C}(-\mathrm{MeOH}$, found: 12.81 , cald.: $12.46 \%$, endotherm), $245^{\circ} \mathrm{C}-380^{\circ} \mathrm{C}$ (decomposition, sharp exotherm), $591^{\circ} \mathrm{C}$ (final plateau, $\mathrm{La}_{2} \mathrm{O}_{3}$, found: 20.91, cald.: $21.11 \%)$.

$\left[\operatorname{Pr}\left(\mathrm{NO}_{3}\right)_{2} \mathrm{~L}\right]\left(\mathrm{NO}_{3}\right) \cdot 3 \mathrm{MeOH}$ (2) Anal. Calc. for $\mathrm{C}_{23} \mathrm{H}_{34} \mathrm{~N}_{7} \mathrm{O}_{14} \operatorname{Pr}$ : C, 35.71; H, 4.44; N, 12.68. Found: C, 35.63\%; H, 4.00\%; N, 12.39\%. Selected IR data $\left(\mathrm{cm}^{-1}\right): 3389 \mathrm{mw}[\mathrm{m}(\mathrm{O}-\mathrm{H})], 3069 \mathrm{w}\left[\mathrm{m}(\mathrm{C}-\mathrm{H})_{\mathrm{ar}}\right], 2981 \mathrm{w}$ $\left[\mathrm{m}(\mathrm{C}-\mathrm{H})_{\mathrm{al}}\right], 1762 \mathrm{~m}, 1731 \mathrm{~m}\left[v_{1}+v_{4}\right.$ of the nitrate $], 1645 \mathrm{~s}$ $[\mathrm{m}(\mathrm{C}=\mathrm{N})], 1592 \mathrm{~ms}, 1571 \mathrm{~m}$ [ring stretching vibrations], 1490 versus $\left[v_{1}\left(A_{1}\right)\right.$ of the nitrate $], 1311$ versus $\left[v_{5}\left(B_{2}\right)\right.$ 
TABLe 2: Selected bond distances $(\AA)$ and angles $\left({ }^{\circ}\right)$ for $\left[\mathrm{Yb}\left(\mathrm{NO}_{3}\right)_{2} \mathrm{~L}\right]\left(\mathrm{NO}_{3}\right) \cdot 2 \mathrm{MeOH}(4)$.

\begin{tabular}{|c|c|c|c|c|}
\hline \multicolumn{5}{|c|}{ Bond distances } \\
\hline $\mathrm{Yb}(1)-\mathrm{N}(2)$ & $2.410(3)$ & $\mathrm{Yb}(1)-\mathrm{O}(6)$ & $2.424(2)$ & \\
\hline $\mathrm{Yb}(1)-\mathrm{O}(4)$ & $2.425(2)$ & $\mathrm{Yb}(1)-\mathrm{O}(1)$ & $2.428(2)$ & \\
\hline $\mathrm{Yb}(1)-\mathrm{N}(3)$ & $2.433(3)$ & $\mathrm{Yb}(1)-\mathrm{O}(2)$ & $2.439(2)$ & \\
\hline $\mathrm{Yb}(1)-\mathrm{O}(7)$ & $2.477(2)$ & $\mathrm{Yb}(1)-\mathrm{N}(1)$ & $2.531(3)$ & \\
\hline $\mathrm{Yb}(1)-\mathrm{N}(4)$ & $2.538(2)$ & $\mathrm{Yb}(1)-\mathrm{O}(3)$ & $2.543(2)$ & \\
\hline $\mathrm{Yb}(1)-\mathrm{N}(6)$ & $2.878(2)$ & $\mathrm{Yb}(1)-\mathrm{N}(5)$ & $2.909(3)$ & \\
\hline \multicolumn{5}{|c|}{ Bond angles } \\
\hline $\mathrm{N}(2)-\mathrm{Yb}(1)-\mathrm{O}(6)$ & $72.51(8)$ & $\mathrm{N}(2)-\mathrm{Yb}(1)-\mathrm{O}(4)$ & $116.04(8)$ & \\
\hline $\mathrm{O}(6)-\mathrm{Yb}(1)-\mathrm{O}(4)$ & $140.00(7)$ & $\mathrm{N}(2)-\mathrm{Yb}(1)-\mathrm{O}(1)$ & $131.78(8)$ & \\
\hline $\mathrm{O}(6)-\mathrm{Yb}(1)-\mathrm{O}(1)$ & $76.60(8)$ & $\mathrm{O}(4)-\mathrm{Yb}(1)-\mathrm{O}(1)$ & $69.55(7)$ & \\
\hline $\mathrm{N}(2)-\mathrm{Yb}(1)-\mathrm{N}(3)$ & $160.59(8)$ & $\mathrm{O}(6)-\mathrm{Yb}(1)-\mathrm{N}(3)$ & $115.07(8)$ & \\
\hline $\mathrm{O}(4)-\mathrm{Yb}(1)-\mathrm{N}(3)$ & $70.63(8)$ & $\mathrm{O}(1)-\mathrm{Yb}(1)-\mathrm{N}(3)$ & $67.34(8)$ & \\
\hline $\mathrm{N}(2)-\mathrm{Yb}(1)-\mathrm{O}(2)$ & $67.19(8)$ & $\mathrm{O}(6)-\mathrm{Yb}(1)-\mathrm{O}(2)$ & $69.61(7)$ & \\
\hline $\mathrm{O}(4)-\mathrm{Yb}(1)-\mathrm{O}(2)$ & $78.14(8)$ & $\mathrm{O}(1)-\mathrm{Yb}(1)-\mathrm{O}(2)$ & $67.75(8)$ & \\
\hline $\mathrm{N}(3)-\mathrm{Yb}(1)-\mathrm{O}(2)$ & $131.79(8)$ & $\mathrm{N}(2)-\mathrm{Yb}(1)-\mathrm{O}(7)$ & $113.47(7)$ & \\
\hline $\mathrm{O}(6)-\mathrm{Yb}(1)-\mathrm{O}(7)$ & $52.03(7)$ & $\mathrm{O}(4)-\mathrm{Yb}(1)-\mathrm{O}(7)$ & $129.66(8)$ & \\
\hline $\mathrm{O}(1)-\mathrm{Yb}(1)-\mathrm{O}(7)$ & $71.37(7)$ & $\mathrm{N}(3)-\mathrm{Yb}(1)-\mathrm{O}(7)$ & $65.75(7)$ & \\
\hline $\mathrm{O}(2)-\mathrm{Yb}(1)-\mathrm{O}(7)$ & $114.18(7)$ & $\mathrm{N}(2)-\mathrm{Yb}(1)-\mathrm{N}(1)$ & $65.39(8)$ & \\
\hline $\mathrm{O}(6)-\mathrm{Yb}(1)-\mathrm{N}(1)$ & $76.95(8)$ & $\mathrm{O}(4)-\mathrm{Yb}(1)-\mathrm{N}(1)$ & $143.01(8)$ & \\
\hline $\mathrm{O}(1)-\mathrm{Yb}(1)-\mathrm{N}(1)$ & $139.88(8)$ & $\mathrm{N}(3)-\mathrm{Yb}(1)-\mathrm{N}(1)$ & $98.00(9)$ & \\
\hline $\mathrm{O}(2)-\mathrm{Yb}(1)-\mathrm{N}(1)$ & $128.01(8)$ & $\mathrm{O}(7)-\mathrm{Yb}(1)-\mathrm{N}(1)$ & $68.60(8)$ & \\
\hline $\mathrm{N}(2)-\mathrm{Yb}(1)-\mathrm{N}(4)$ & $98.28(8)$ & $\mathrm{O}(6)-\mathrm{Yb}(1)-\mathrm{N}(4)$ & $145.03(7)$ & \\
\hline $\mathrm{O}(4)-\mathrm{Yb}(1)-\mathrm{N}(4)$ & $74.70(7)$ & $\mathrm{O}(1)-\mathrm{Yb}(1)-\mathrm{N}(4)$ & $127.32(8)$ & \\
\hline $\mathrm{N}(3)-\mathrm{Yb}(1)-\mathrm{N}(4)$ & $64.96(9)$ & $\mathrm{O}(2)-\mathrm{Yb}(1)-\mathrm{N}(4)$ & $138.96(7)$ & \\
\hline $\mathrm{O}(7)-\mathrm{Yb}(1)-\mathrm{N}(4)$ & $106.83(7)$ & $\mathrm{N}(1)-\mathrm{Yb}(1)-\mathrm{N}(4)$ & $68.74(8)$ & \\
\hline $\mathrm{N}(2)-\mathrm{Yb}(1)-\mathrm{O}(3)$ & $67.07(8)$ & $\mathrm{O}(6)-\mathrm{Yb}(1)-\mathrm{O}(3)$ & $131.84(7)$ & \\
\hline $\mathrm{O}(4)-\mathrm{Yb}(1)-\mathrm{O}(3)$ & $51.21(8)$ & $\mathrm{O}(1)-\mathrm{Yb}(1)-\mathrm{O}(3)$ & $112.70(7)$ & \\
\hline $\mathrm{N}(3)-\mathrm{Yb}(1)-\mathrm{O}(3)$ & $111.73(8)$ & $\mathrm{O}(2)-\mathrm{Yb}(1)-\mathrm{O}(3)$ & $71.32(7)$ & \\
\hline $\mathrm{O}(7)-\mathrm{Yb}(1)-\mathrm{O}(3)$ & $174.40(7)$ & $\mathrm{N}(1)-\mathrm{Yb}(1)-\mathrm{O}(3)$ & $107.42(8)$ & \\
\hline $\mathrm{N}(4)-\mathrm{Yb}(1)-\mathrm{O}(3)$ & $67.71(7)$ & $\mathrm{N}(2)-\mathrm{Yb}(1)-\mathrm{N}(6)$ & $93.83(7)$ & \\
\hline $\mathrm{O}(4)-\mathrm{Yb}(1)-\mathrm{N}(6)$ & $140.30(7)$ & $\mathrm{O}(1)-\mathrm{Yb}(1)-\mathrm{N}(6)$ & $71.05(7)$ & \\
\hline $\mathrm{N}(3)-\mathrm{Yb}(1)-\mathrm{N}(6)$ & $90.01(8)$ & $\mathrm{O}(2)-\mathrm{Yb}(1)-\mathrm{N}(6)$ & $91.46(7)$ & \\
\hline $\mathrm{N}(1)-\mathrm{Yb}(1)-\mathrm{N}(6)$ & $71.87(8)$ & $\mathrm{N}(4)-\mathrm{Yb}(1)-\mathrm{N}(6)$ & $128.73(7)$ & \\
\hline $\mathrm{O}(3)-\mathrm{Yb}(1)-\mathrm{N}(6)$ & $57.89(7)$ & $\mathrm{N}(2)-\mathrm{Yb}(1)-\mathrm{N}(5)$ & $91.86(8)$ & \\
\hline $\mathrm{O}(6)-\mathrm{Yb}(1)-\mathrm{N}(5)$ & $143.58(7)$ & $\mathrm{O}(1)-\mathrm{Yb}(1)-\mathrm{N}(5)$ & $91.67(7)$ & \\
\hline $\mathrm{N}(3)-\mathrm{Yb}(1)-\mathrm{N}(5)$ & $90.64(8)$ & $\mathrm{O}(2)-\mathrm{Yb}(1)-\mathrm{N}(5)$ & $74.03(7)$ & \\
\hline $\mathrm{O}(7)-\mathrm{Yb}(1)-\mathrm{N}(5)$ & $154.67(7)$ & $\mathrm{N}(1)-\mathrm{Yb}(1)-\mathrm{N}(5)$ & $126.83(8)$ & \\
\hline $\mathrm{N}(4)-\mathrm{Yb}(1)-\mathrm{N}(5)$ & $68.13(7)$ & $\mathrm{N}(6)-\mathrm{Yb}(1)-\mathrm{N}(5)$ & $160.92(7)$ & \\
\hline \multicolumn{5}{|c|}{ Structural characteristics of $\mathrm{H}$-bonds } \\
\hline \multicolumn{2}{|c|}{$\mathrm{D}-\mathrm{H} \cdots \mathrm{A}$} & $\mathrm{d}(\mathrm{H} \cdots \mathrm{A})$ & $\mathrm{d}(\mathrm{D} \cdots \mathrm{A})$ & $<(\mathrm{DHA})$ \\
\hline \multicolumn{2}{|c|}{$\mathrm{O}(12)-\mathrm{H}(4 \mathrm{~S}) \cdots \mathrm{O}(11)$} & $1.89(8)$ & $2.828(4)$ & $156(7)$ \\
\hline \multicolumn{2}{|c|}{$\mathrm{O}(13)-\mathrm{H}(8 \mathrm{~S}) \cdots \mathrm{O}(12) \# 1$} & $0.98(5)$ & $2.758(4)$ & $170(5)$ \\
\hline
\end{tabular}

Symmetry transformations used to generate equivalent atoms: $\# 1-x+2, y-(1 / 2),-z+(3 / 2)$.

of the nitrate], $1020 \mathrm{~m}\left[\nu_{2}\left(\mathrm{~A}_{1}\right)\right.$ of the nitrate], $637 \mathrm{~m}$ $[\delta(\mathrm{py})], 406 \mathrm{w}[\gamma(\mathrm{py})] . \mu_{\mathrm{eff}}=3.47 \mathrm{BM}$ at $21^{\circ} \mathrm{C}$. TGA/DTA $\left(\mathrm{N}_{2}, 1 \mathrm{~atm}\right): 61^{\circ} \mathrm{C}-92^{\circ} \mathrm{C}$ (-MeOH, found: 12.01, cald.: $12.43 \%$, endotherm), $257^{\circ} \mathrm{C}-337^{\circ} \mathrm{C}$ (decomposition, sharp exotherm), $547^{\circ} \mathrm{C}$ (final plateau, $\operatorname{Pr}_{6} \mathrm{O}_{11}$, found: 21.99 , cald.: $22.01 \%)$.
$\left[\mathrm{Gd}\left(\mathrm{NO}_{3}\right)_{2} \mathrm{~L}\right]\left(\mathrm{NO}_{3}\right) \cdot 2 \mathrm{MeOH}$ (3) Anal. Calc. for $\mathrm{C}_{22} \mathrm{H}_{30} \mathrm{~N}_{7} \mathrm{O}_{13} \mathrm{Gd}$ : C, 34.86; $\mathrm{H}, 4.00 ; \mathrm{N}, 12.94$. Found: C, $34.87 ; \mathrm{H}, 3.72 ; \mathrm{N}, 13.00 \%$. Selected IR data $\left(\mathrm{cm}^{-1}\right): 3386 \mathrm{mw}$ $[\mathrm{m}(\mathrm{O}-\mathrm{H})], \quad 3070 \mathrm{w} \quad\left[\mathrm{m}(\mathrm{C}-\mathrm{H})_{\mathrm{ar}}\right], \quad 2982 \mathrm{w} \quad\left[\mathrm{m}(\mathrm{C}-\mathrm{H})_{\mathrm{al}}\right]$, $1767 \mathrm{~m}, 1734 \mathrm{~m}\left[\nu_{1}+\nu_{4}\right.$ of the nitrate], $1642 \mathrm{~s}[\mathrm{~m}(\mathrm{C}=\mathrm{N})]$, $1590 \mathrm{~ms}, 1573 \mathrm{~m}$ [ring stretching vibrations], 1488 versus 


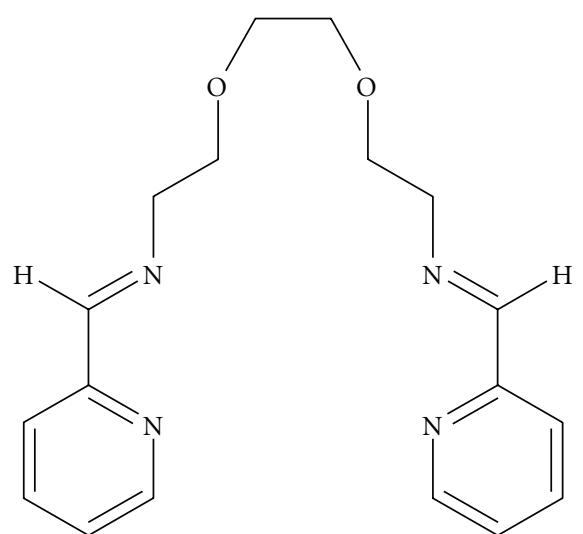

Scheme 1: The ligand (NE,N'E)-2,2'-(ethane-1,2-diylbis(oxy)) bis(N-(pyridin-2-yl-methylene)ethanamine) (L).

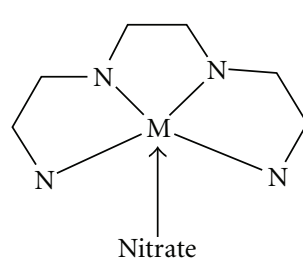

(a)

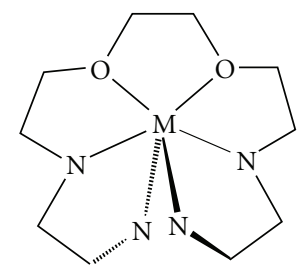

(b)
Scheme 2: A schematic representation of the coordination of the Schiff base ligands used, to lanthanides. (a) References 18-21, (b) This work.

[ $\nu_{1}\left(\mathrm{~A}_{1}\right)$ of the nitrate], 1310 versus $\left[\nu_{5}\left(\mathrm{~B}_{2}\right)\right.$ of the nitrate], $1030 \mathrm{~m}\left[\nu_{2}\left(\mathrm{~A}_{1}\right)\right.$ of the nitrate $], 630 \mathrm{~m}[\delta(\mathrm{py})], 417 \mathrm{w}[\gamma(\mathrm{py})]$. $\mu_{\text {eff }}=7.96 \mathrm{BM}$ at $21^{\circ} \mathrm{C}$. TGA/DTA $\left(\mathrm{N}_{2}, 1 \mathrm{~atm}\right): 51^{\circ} \mathrm{C}-70^{\circ} \mathrm{C}$ (-MeOH, found: 8.98 , cald.: $9.12 \%$, endotherm), $283^{\circ} \mathrm{C}-$ $345^{\circ} \mathrm{C}$ (decomposition, sharp exotherm), $508^{\circ} \mathrm{C}$ (final plateau, $\mathrm{Gd}_{2} \mathrm{O}_{3}$, found: 23.57 , cald.: $23.92 \%$ ).

$\left[\mathrm{Yb}\left(\mathrm{NO}_{3}\right)_{2} \mathrm{~L}\right]\left(\mathrm{NO}_{3}\right) \cdot 2 \mathrm{MeOH}$ (4) Anal. Calc. for $\mathrm{C}_{22} \mathrm{H}_{30} \mathrm{~N}_{7} \mathrm{O}_{13} \mathrm{Yb}$ : C, 34.15; H, 3.92; N, 12.68. Found: C, 34.17; H, 3.77; N, 13.59\%. Selected IR data $\left(\mathrm{cm}^{-1}\right): 3401 \mathrm{mw}$ $[\mathrm{m}(\mathrm{O}-\mathrm{H})], \quad 3078 \mathrm{w} \quad\left[\mathrm{m}(\mathrm{C}-\mathrm{H})_{\mathrm{ar}}\right], \quad 2967 \mathrm{w} \quad\left[\mathrm{m}(\mathrm{C}-\mathrm{H})_{\mathrm{al}}\right]$, $1762 \mathrm{~m}, 1738 \mathrm{~m}\left[\nu_{1}+v_{4}\right.$ of the nitrate $], 1633 \mathrm{~s}[\mathrm{~m}(\mathrm{C}=\mathrm{N})]$, $1581 \mathrm{~ms}, 1562 \mathrm{~m}$ [ring stretching vibrations], 1497 versus [ $\nu_{1}\left(\mathrm{~A}_{1}\right)$ of the nitrate], 1308 versus $\left[\nu_{5}\left(\mathrm{~B}_{2}\right)\right.$ of the nitrate], $1039 \mathrm{~m}\left[\nu_{2}\left(\mathrm{~A}_{1}\right)\right.$ of the nitrate $], 618 \mathrm{~m}[\delta(\mathrm{py})], 422 \mathrm{w}[\gamma(\mathrm{py})]$. $\mu_{\text {eff }}=7.96 \mathrm{BM}$ at $21^{\circ} \mathrm{C}$. TGA/DTA $\left(\mathrm{N}_{2}, 1 \mathrm{~atm}\right): 48^{\circ} \mathrm{C}-71^{\circ} \mathrm{C}$ (-MeOH, found: 8.45 , cald.: $8.80 \%$, endotherm), $288^{\circ} \mathrm{C}-$ $361^{\circ} \mathrm{C}$ (decomposition, sharp exotherm), $545^{\circ} \mathrm{C}$ (final plateau, $\mathrm{Yb}_{2} \mathrm{O}_{3}$, found: 25.01 , cald.: $25.47 \%$ ).

2.3. X-Ray Crystallography. X-ray crystal data (Table 1) were collected at $93 \mathrm{~K}$ by using a Rigaku MM007 High brilliance RA generator/confocal optics and Mercury CCD system. Intensities were corrected for Lorentz polarization and for absorption. The structure was solved by direct methods [SIR97]. [25] Hydrogen atoms bound to carbon were idealised. Structural refinement was obtained with full-matrix leastsquares based on $F^{2}$ by using the program SHELXL. [26] The crystal was a racemic twin and refined smoothly using TWIN and BASF commands incorporated in SHELX. CCDC 776362 contains the supplementary crystallographic data for this paper. These data can be obtained free of charge via http://www.ccdc.cam.ac.uk/conts/retrieving.html or from the Cambridge Crystallographic Data centre, 12 Union Road, Cambridge CB2 1EZ, UK; fax (+44) 1223-336033; E-mail: deposit@ccdc.cam.ac.uk.

\section{Results and Discussion}

Complexes 1-4 were prepared by direct reaction of the hydrated lanthanide nitrate salts and the Schiff base ligand starting materials in methanol in $1: 1: 2$ metal to diamine to aldehyde molar ratio. Though it seems that the ligand (Scheme 1) can be prepared by the direct reaction of its constituents (2, 2' -(ethane-1,2-diylbis(oxy))diethanamine and pyridine-2-carboxaldehyde in 1:2 molar ratio), it was impossible to isolate it in a solid form. This is probably due to the relatively long dietheric chain between the Schiff base moieties. Attempts to prepare the 1:2 complexes using larger excess of the ligand parts and different solvents lead to impure products with unidentified formulae.

The crystal structure of complex 4 (Figure 1(a)) consists of cationic complexes $\left[\mathrm{Yb}\left(\mathrm{NO}_{3}\right)_{2} \mathrm{~L}\right]^{+}$, nitrate anions, and two methanol molecules per metal ion held together with hydrogen bonds and $\mathrm{C}-\mathrm{H} \cdots \pi$ interactions. The $\mathrm{Yb}^{\mathrm{III}}$ atom, being ten coordinated, is surrounded by six oxygen atoms belonging to two bidentate chelating nitrato ligands and to the etherate part of the ligand and four (two imino and two pyridine) nitrogen atoms belonging to the Schiff base ligand. The coordination polyhedron is much distorted and can be better described, according to Robertson [27], being between a Hoard dodecahedron and a decatetrahedron. (Figure 1(b)).

The $\mathrm{Yb}-\mathrm{O}$ bond distances span the range 2.424-2.543 $\AA$ and they are in good agreement with previously reported values $[7,8,17-21,28]$, taking into account the lanthanide contraction. Though neutral, the etheric oxygen atoms appear to be coordinated to $\mathrm{Yb}^{\mathrm{III}}$ stronger than the nitrates $\left(\right.$ mean $\mathrm{Yb}-\mathrm{O}_{\text {nitrato }}=2.47, \mathrm{Yb}-\mathrm{O}_{\text {ether }}=2.43 \AA$ ). There are two probable reasons for this behavior: (a) the macrochelate effect, since the ligand contains six sequential donor atoms and (b) the coordination behavior of the nitrato ligands which are both assymetrically chelated. There are no important differences in the coordination characteristics of the nitrato ligands. Additionally, both of the coordinated nitrates are coplanar to $\mathrm{Yb}(1)$, as indicated by the $\mathrm{Yb}(1)-\mathrm{O}_{\text {coordinated }}-$ $\mathrm{N}-\mathrm{O}_{\text {free }}$ torsion angles which are all larger than $175^{\circ} \mathrm{C}$. The mean $\mathrm{Yb}-\mathrm{N}$ distance is $2.478 \AA$, with the $\mathrm{Yb}-\mathrm{N}_{\text {imino }}$ being shorter than the corresponding $\mathrm{Yb}-\mathrm{N}_{\text {pyridine }}$ and is in agreement with our previous data [19-21].

The major differences from our previous work on lanthanoid coordination chemistry with Schiff bases rise from the size and the denticity of the ligand. When tetradentate $\mathrm{N}_{4}$ ligands were used, (Scheme 2(a)) the four nitrogen donor atoms are coplanar and the metal ion lies approximately on the plane formed. There is also space for a nitrato ligand to approach and bind the lanthanide cation. In the present case, the two chelating pyridine Schiff base coordination sites 


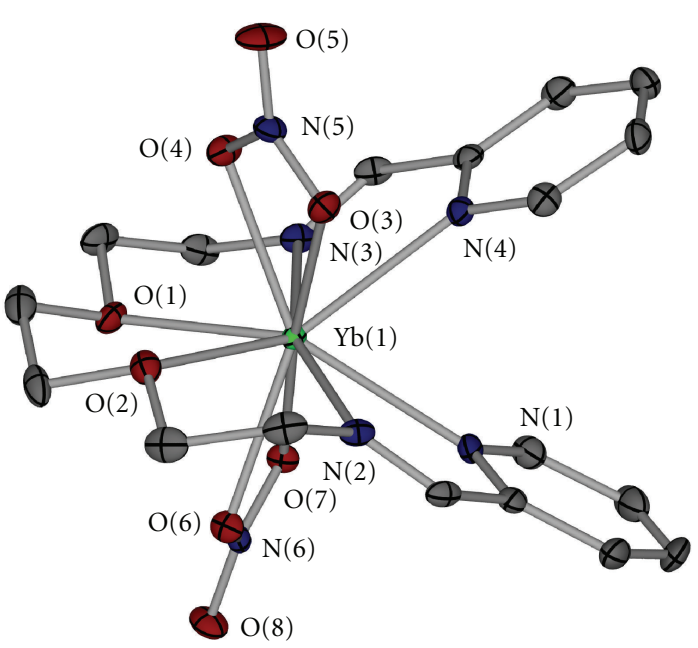

(a)

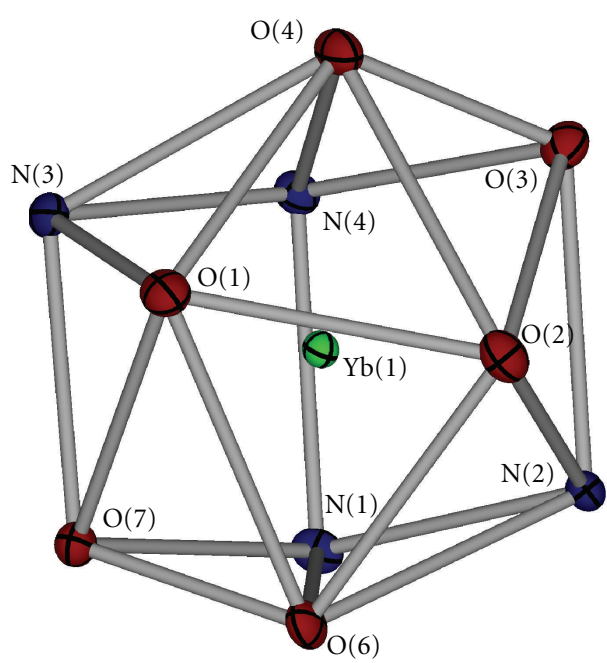

(b)

FIGURE 1: (a) A thermal ellipsoid plot of the cation in 4, including a partial labelling scheme. The hydrogen atoms have been omitted for clarity. (b) The coordination polyhedron about $\mathrm{Yb}(1)$ in 4 .

exist, but their distances have been significantly increased. In addition, between the nitrogen chelating sites are present two more oxygen donor atoms which eventually bind the lanthanide. (Scheme 2(b)) Furthermore, there is no space to accommodate six donor atoms on the same plane about $\mathrm{Yb}^{\mathrm{III}}$ and this results in the exclusion of the pyridine nitrogen away of the plane formed (max deviation from the mean plane: $0.051 \AA$ ) by the two oxygen and the two imino nitrogen atoms. This way the two pyridine rings are pointing up and down of the plane with a dihedral angle of 53.846(5) . With the tetradentate Schiff bases being coordinated to lanthanides, there is enough room for three nitrato ligands to coordinate to the metal. Increasing the denticity of the ligand to six, only two nitrato ligands appear in the coordination sphere of the metal.

The ionic nitrate interacts with H-bonds with the solvated methanol molecules. Surprisingly, the coordinated nitrates are not involved in hydrogen bonding interactions. This is probably due to their location in cavities with organic surfaces in the crystal.

Comparison of the infrared spectra of the prepared complexes can lead us rather safely to the conclusion that the four complexes are isostructural or at least that both the nitrato and the Schiff base ligands are coordinated in the same manner. Assignment of the nitrate bands has been made as reported previously [29].

The room temperature effective magnetic moments of complexes 2, 3, and 4 show little deviation from the Van Vleck theoretical values.

The values of the bonding parameters $\beta$ (nephelauxetic ratio) and $\delta$ (Sinha's parameter) of the $\mathrm{Pr}^{\mathrm{III}}$ complex 2 are calculated from the solid state $f-f$ spectra by standard equations. Those are 1.003 and -0.30 , respectively, and they suggest that the interaction between the trivalent lanthanide and the ligands is essentially electrostatic and that there is very small participation of the $4 f$ orbitals in bonding [30].
All complexes behave similarly when heated under nitrogen. Complexes 1 and 2 lose their solvated methanol molecules above its boiling point, while $\mathbf{3}$ and $\mathbf{4}$ lose the solvated molecules about methanol's boiling point. This is an indication of stronger $\mathrm{H}$-bonding in their structures. The intermediates are reasonably stable (up to ca. $280^{\circ} \mathrm{C}$ ) and decompose violently due to the nitrates. The final residues, which are obtained above $490^{\circ} \mathrm{C}$, correspond to the sesquioxides except for 2 , which corresponds to $\operatorname{Pr}_{6} \mathrm{O}_{11}$.

Preliminary relaxometric data have shown that 3 is pretty stable in aqueous medium in addition to its increased solubility due to the ionic character. Tailoring, with major goal to increase the stability of lanthanide complexes, of new ligands based on the Schiff base described here and previously [18-22] is in progress.

\section{Acknowledgments}

This research was cofunded by the European Union in the framework of the program "Heraklitos" of the "Operational Program for Education and Initial Vocational Training" of the 3rd Community Support Framework of the Hellenic Ministry of Education, funded by 25\% from national sources and by 75\% from the European Social Fund (ESF).

\section{References}

[1] M. A. V. Ribeiro da Silva, M. D. M. C. Ribeiro da Silva, M. J. S. Monte, J. M. Gonçalves, and É. M. R. Fernandes, "Energetics of metal-ligand binding in copper(II) and nickel(II) complexes of two Schiff bases," Journal of the Chemical Society, Dalton Transactions, no. 7, pp. 1257-1262, 1997.

[2] V. Alexander, "Design and synthesis of macrocyclic ligands and their complexes of lanthanides and actinides," Chemical Reviews, vol. 95, no. 2, pp. 273-342, 1995. 
[3] R. B. Lauffer, "Paramagnetic metal complexes as water proton relaxation agents for NMR imaging: theory and design," Chemical Reviews, vol. 87, no. 5, pp. 901-927, 1987.

[4] J. Hall, R. Häner, S. Aime et al., "Relaxometric and luminescence behaviour of triaquahexaazamacrocyclic complexes, the gadolinium complex displaying a high relaxivity with a pronounced $\mathrm{pH}$ dependence," New Journal of Chemistry, vol. 22, no. 6, pp. 627-631, 1998.

[5] P. H. Smith, J. R. Brainard, D. E. Morris, G. D. Jarvinen, and R. R. Ryan, "Solution and solid-state characterization of europium and gadolinium schiff base complexes and assessment of their potential as contrast agents in magnetic resonance imaging," Journal of the American Chemical Society, vol. 111, no. 19, pp. 7437-7443, 1989.

[6] J. de O. Cabral, M. F. Cabral, W. J. Cummins, M. G. B. Drew, A. Rodgers, and S. M. Nelson, "Hexagonal bipyramidal alkaline earth and lead(II) complexes of a hexa-imine macrocyclic ligand," Inorganica Chimica Acta, vol. 30, pp. L313-L316, 1978.

[7] J. D. J. Backer-Dirks, C. J. Gray, F. A. Hart, M. B. Hursthouse, and B. C. Schoop, "Preparation and properties of complexes of lanthanides with a hexadentate nitrogen-donor macrocycle: X-ray crystal structure of the complex $\left[\mathrm{La}\left(\mathrm{NO}_{3}\right)_{3} \mathrm{~L}\right]$," Journal of the Chemical Society, Chemical Communications, no. 17, pp. 774-775, 1979.

[8] A. M. Arif, J. D. J. Backer-Dirks, C. J. Gray, F. A. Hart, and M. B. Hursthouse, "Syntheses, X-ray structures, and properties of complexes of macrocyclic hexaimines with lanthanide nitrates," Journal of the Chemical Society, Dalton Transactions, no. 7, pp. 1665-1673, 1987.

[9] G. Bombieri, F. Benetollo, A. Polo, L. De Cola, D. L. Smailes, and L. M. Vallarino, "Synthesis, characterization, and crystal structure of a hexaaza macrocyclic complex of lutetium(III)," Inorganic Chemistry, vol. 25, no. 8, pp. 1127-1132, 1986.

[10] F. Benetollo, A. Polo, G. Bombieri, K. K. Fonda, and L. M. Vallarino, "X-ray crystal structures and nuclear magnetic resonance spectra of macrocyclic complexes of neodymium(III) and europium(III)," Polyhedron, vol. 9, no. 11, pp. 1411-1422, 1990.

[11] G. Bombieri, F. Benetollo, A. Polo, K. K. Fonda, and L. M. Vallarino, "NMR, luminescence, and X-ray crystallographic studies of the interaction of uncharged $\mathrm{N}$-donor ligands with europium(III) in the macrocyclic complex $\left[\mathrm{Eu}\left(\mathrm{CH}_{3} \mathrm{COO}\right)_{2}\left(\mathrm{C}_{22} \mathrm{H}_{26} \mathrm{~N}_{6}\right)\right] \mathrm{Cl} \cdot 4\left(\mathrm{H}_{2} \mathrm{O}\right)$," Polyhedron, vol. 10, no. 12, pp. 1385-1394, 1991.

[12] S. W. A. Bligh, N. Choi, W. J. Cummins, E. G. Evagorou, J. D. Kelly, and M. McPartlin, "Yttrium(III) and lanthanide(III) metal complexes of an 18-membered hexaaza tetraimine macrocycle-crystal structure of the gadolinium(III) complex," Journal of the Chemical Society, Dalton Transactions, no. 23, pp. 3369-3376, 1994.

[13] F. Benetollo, G. Bombieri, K. K. Fonda, and L. M. Vallarino, "Interaction of $\beta$-diketones with $\mathrm{La}^{\mathrm{III}}, \mathrm{Eu}^{\mathrm{III}}$ and $\mathrm{Y}^{\mathrm{III}}$ complexes of the six-nitrogen-donor macrocyclic ligand $\mathrm{C}_{22} \mathrm{H}_{26} \mathrm{~N}_{6}$ and crystal structure of $\left[\mathrm{Eu}\left(\mathrm{CH}_{3} \mathrm{COO}\right) *\left(\mathrm{C}_{6} \mathrm{H}_{5} \mathrm{CO}\right)_{2} \mathrm{CH} *\right.$ $\left.\left(\mathrm{C}_{22} \mathrm{H}_{26} \mathrm{~N}_{6}\right)\right]\left(\mathrm{CH}_{3} \mathrm{COO}\right) \cdot 6\left(\mathrm{H}_{2} \mathrm{O}\right)$," Polyhedron, vol. 16, no. 11, pp. 1907-1919, 1997.

[14] G. Bomibieri, F. Benetollo, A. Polo, L. De Cola, W. T. Hawkins, and L. M. Vallarino, "Synthesis, characterization, and $\mathrm{x}$-ray crystal structure of tris-isothiocyanato complexes of the yttrium(III) and europium(III) ions with a six-nitrogendonor macrocyclic ligand," Polyhedron, vol. 8, no. 17, pp. 2157-2167, 1989.
[15] K. K. Fonda, D. L. Smailes, L. M. Vallarino et al., "Interaction of neutral and anionic o-donor organic ligands with europium(III) in the macrocyclic complex $\left[\mathrm{Eu}\left(\mathrm{CH}_{3} \mathrm{COO}\right)_{2}\left(\mathrm{C}_{22} \mathrm{H}_{26} \mathrm{~N}_{6}\right)\right] \mathrm{Cl} \cdot 4 \mathrm{H}_{2} \mathrm{O}$ and crystal structure of $\left[\mathrm{Eu}\left(\mathrm{CH}_{3} \mathrm{COO}\right)_{2}\left(\mathrm{C}_{22} \mathrm{H}_{26} \mathrm{~N}_{6}\right)\right]\left(\mathrm{CH}_{3} \mathrm{COO}\right) \cdot 9 \mathrm{H}_{2} \mathrm{O}$," Polyhedron, vol. 12, no. 5, pp. 549-562, 1993.

[16] S. W. A. Bligh, N. Choi, E. G. Evagorou, M. McPartlin, and K. N. White, "Dimeric yttrium(III) and neodymium(III) macrocyclic complexes: potential catalysts for hydrolysis of double-stranded DNA," Journal of the Chemical Society, Dalton Transactions, no. 21, pp. 3169-3172, 2001.

[17] M. G. B. Drew, M. R. St. J. Foreman, M. J. Hudson, and K. F. Kennedy, "Structural studies of lanthanide complexes with tetradentate nitrogen ligands," Inorganica Chimica Acta, vol. 357, no. 14, pp. 4102-4112, 2004.

[18] S. Kano, H. Nakano, M. Kojima, N. Baba, and K. Nakajima, "An effect of the ionic radii of lanthanide(III) ions on the structure and catalytic properties of chiral Schiff baselanthanide(III) complexes," Inorganica Chimica Acta, vol. 349, pp. 6-16, 2003.

[19] S. Gourbatsis, J. C. Plakatouras, V. Nastopoulos, C. J. Cardin, and N. Hadjiliadis, " $\left[\operatorname{Pr}\left(\mathrm{NO}_{3}\right)_{3} \mathrm{~L}\right]$ : a mononuclear ten-coordinate lanthanide(III) complex with a tetradentate diSchiff base," Inorganic Chemistry Communications, vol. 2, no. 10, pp. 468-471, 1999.

[20] M. Tsiouri, J. C. Plakatouras, A. Garoufis, V. Nastopoulos, and N. Hadjiliadis, "Interactions of trivalent lanthanide cations with tetradentate schiff bases. Synthesis and characterization of lanthanide(III) complexes with $\mathrm{N}, \mathrm{N}^{\prime}$-bis(pyridin-2-ylmethylene)benzene-1,2-diamine," Inorganic Chemistry Communications, vol. 5, no. 10, pp. 844-847, 2002.

[21] M. Tsiouri, N. Hadjiliadis, T. Arslan, B. M. Kariuki, and J. C. Plakatouras, "Interactions of trivalent lanthanide cations with tetradentate Schiff bases: new lanthanide(III) complexes from $\left(1 S, 2 S, N^{1} E, N^{2} E\right)$-N, $\mathrm{N}^{\prime}$-bis(pyridin-2-ylmethylene)cyclohexane-1,2-diamine," Inorganic Chemistry Communications, vol. 9, no. 4, pp. 429-432, 2006.

[22] T. Arslan, C. Öğretir, M. Tsiouri, J. C. Plakatouras, and N. Hadjiliadis, "Interactions of trivalent lanthanide cations with a hexadentate Schiff base derived from the condensation of ethylenediamine with 8-hydroxyquinoline-2- carboxaldehyde," Journal of Coordination Chemistry, vol. 60, no. 6, pp. 699-710, 2007.

[23] F. J. Quaeyhaegens, H. O. Desseyn, S. P. Perlepes, J. C. Plakatouras, B. Bracke, and A. T. H. Lenstra, "Synthesis, spectroscopy and thermal properties of the nickel(II), palladium(II) and copper(II) complexes of bis(aminoalkyl)oxamides $\left(=\mathrm{LH}_{2}\right)$ including the crystal structure of $\mathrm{Cu}_{2} \mathrm{~L}\left(\mathrm{NO}_{3}\right)_{2}$," Transition Metal Chemistry, vol. 16, no. 1, pp. 92-101, 1991.

[24] M. Mylonas, A. Kretzel, J. C. Plakatouras, N. Hadjiliadis, and W. Bal, "The binding of $\mathrm{Ni}(\mathrm{II})$ ions to terminally blocked hexapeptides derived from the metal binding -ESHH- motif of histone H2A," Journal of the Chemical Society, Dalton Transactions, no. 22, pp. 4296-4306, 2002.

[25] A. Altomare, M. C. Burla, M. Camalli et al., "SIR97: a new tool for crystal structure determination and refinement," Journal of Applied Crystallography, vol. 32, no. 1, pp. 115-119, 1999.

[26] G. M. Sheldrick, SHELX97-Programs for Crystal Structure Analysis (Release 97-2), Institüt für Anorganische Chemie der Universität, Göttingen, Germany, 1998. 
[27] B. E. Robertson, "Coordination polyhedra with nine and ten atoms," Inorganic Chemistry, vol. 16, no. 11, pp. 2735-2742, 1977.

[28] I. Baxter, S. R. Drake, M. B. Hursthouse et al., "Effect of polyether ligands on stabilities and mass transport properties of a series of gadolinium(III) $\beta$-diketonate complexes," Inorganic Chemistry, vol. 34, no. 6, pp. 1384-1394, 1995.

[29] A. B. P. Lever, E. Mantovani, and B. S. Ramaswamy, "Infrared combination frequencies in coordination complexes containing nitrate groups in various coordination environmentsprobe for metal-nitrate interaction," Canadian Journal of Chemistry, vol. 49, no. 11, pp. 1956-1965, 1971.

[30] R. K. Agarwal, K. Arora, and R. K. Sarin, "Magneto and spectral studies of lanthanide(III) nitrate complexes of 4vinylpyridine," Synthesis and Reactivity in Inorganic and MetalOrganic Chemistry, vol. 24, no. 5, pp. 735-747, 1994. 


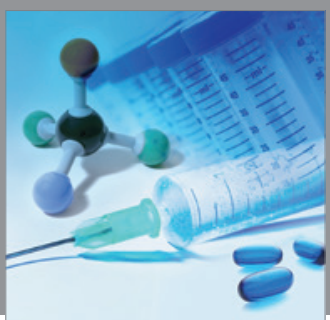

International Journal of

Medicinal Chemistry

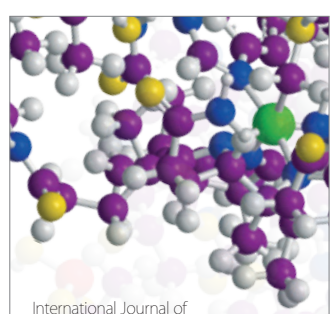

Carbohydrate Chemistry

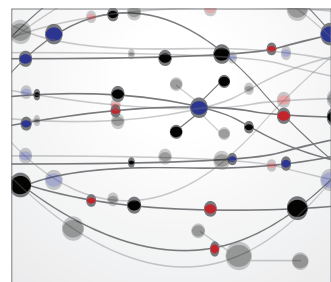

The Scientific World Journal
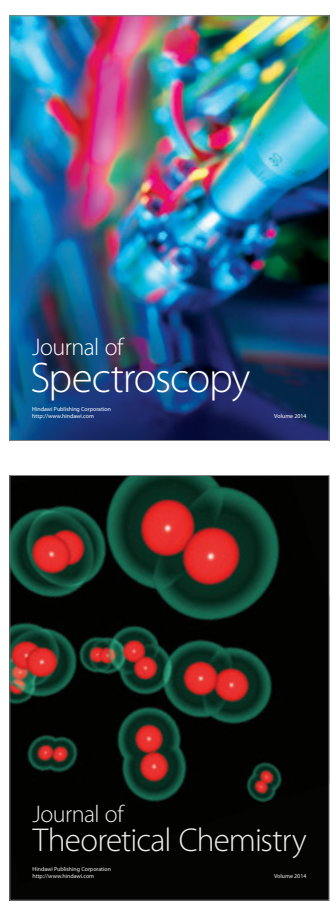
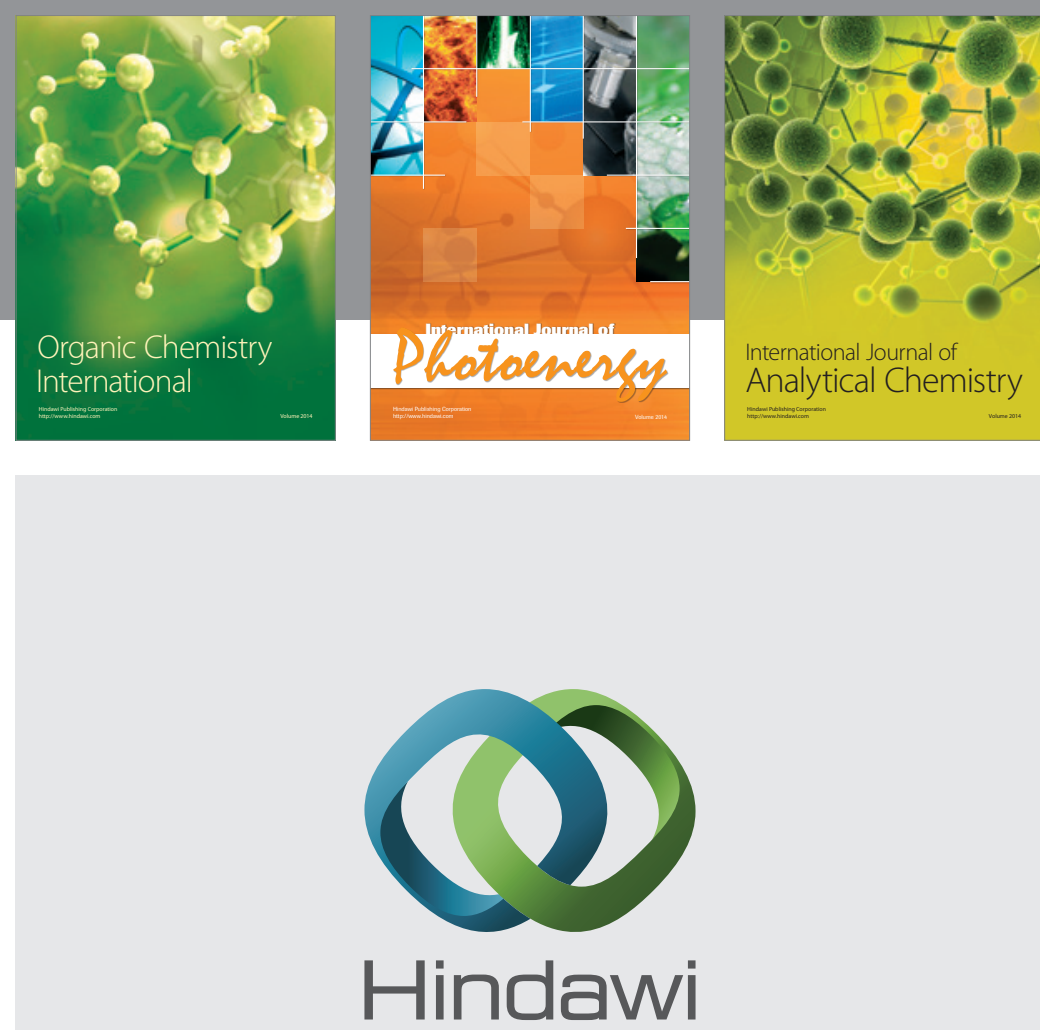

Submit your manuscripts at

http://www.hindawi.com
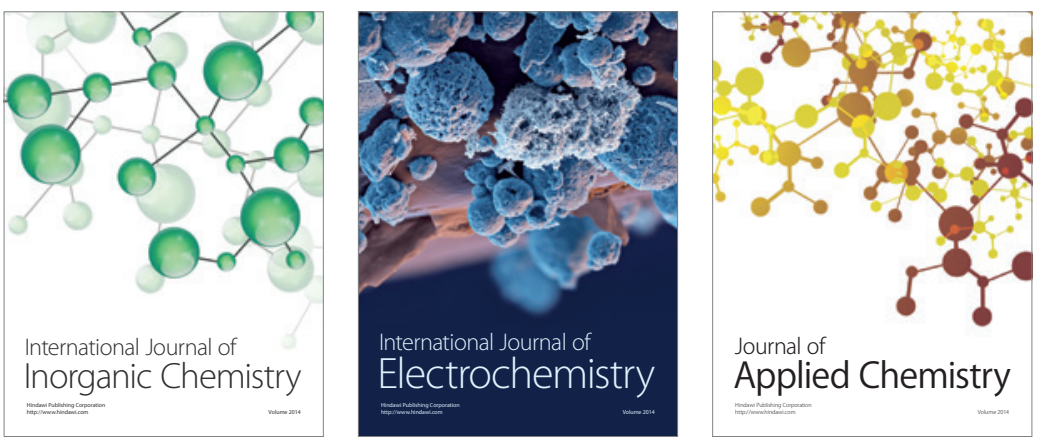

Journal of

Applied Chemistry
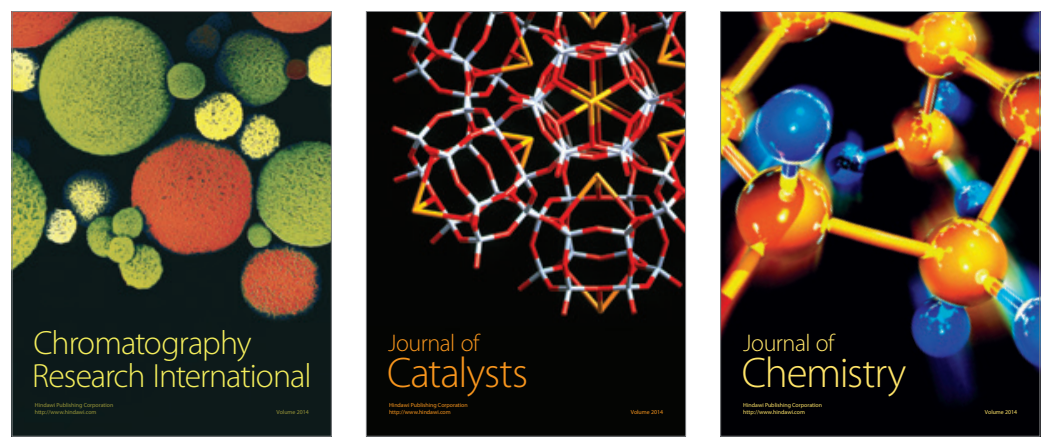
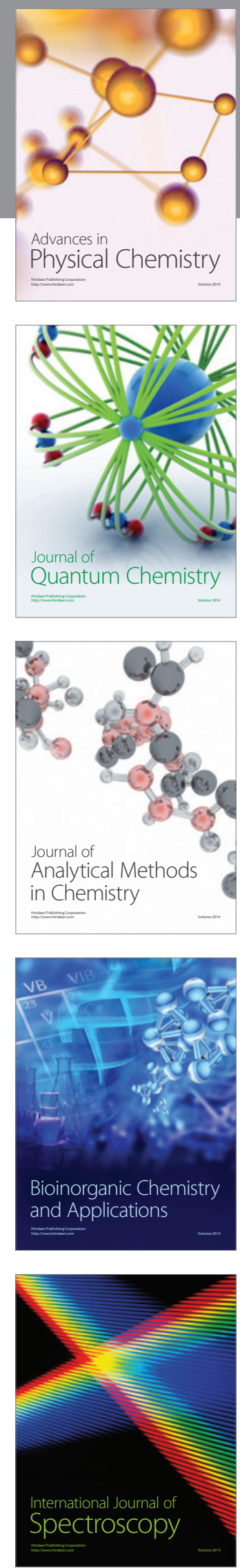